\title{
The Architectural Structure of Joglo House as the Manifestation of Javanese Local Wisdom
}

\author{
E N Widayati ${ }^{1}$, N E Rakhmawati ${ }^{2,}$ and D Pratama ${ }^{3}$ \\ STT Sapta Taruna, Jakarta, Indonesia ${ }^{1}$ \\ STIKes Istara Nusantara, Jakarta, Indonesia ${ }^{2}$ \\ Universitas Indraprasta PGRI, Jakarta, Indonesia ${ }^{3}$ \\ \{eko.nurlita@gmail.com ${ }^{1}$,nurendah_r@yahoo.com $\left.{ }^{2}\right\}$
}

\begin{abstract}
Joglo House is a traditional Javanese house with a pyramid-like roof which resembles the form of a mountain. The Javanese people believe that the mountain is a symbol of all sacred things. Joglo House contains a Javanese philosophy which sees house as a link between the earth and the sky because the house was located at the center between the two. The complete structure of the traditional Javanese house consists of several buildings, namely the front house consisting of pendopo and pringgitan, the side house called gandhok, the main house called dalem, and the back house which consists of gadri, pekiwan, and gedogan. The service area, which includes the pawon (kitchen) and pekiwan (well and bathroom), is located in the back and separated from the main house. This is different from house structure in general, where the kitchen and bathroom are in the main house. This paper will explore the design of Joglo House, especially related to the location of the service area, using a qualitative research method with exploration design to understand the philosophy behind this architectural structure. The result shows that the structure of Joglo House was a manifestation of the Javanese local wisdom that embrace the public courtesy in the community without sacrificing the importance of privacy.
\end{abstract}

Keywords: Joglo House, Javanese Culture, Architectural Structure, Local Wisdom.

\section{Introduction}

Houses in Javanese society are considered to be the link between heaven and earth. Houses in Javanese are called omah, which is a combination of the word om and mah. Om means sky (fatherly figure) and mah is a motherly figure. So omah is a symbol of the father (sky) and the mother (earth) [1]. There were several types of Javanese traditional house based on the shape of the roof as shown in figure 1, where it indicates the social status of the owner. Figure 1 includes the shape of traditional houses such as Joglo, Limasan, Kampung, Tajuk, and Panggang-pe. However, even though it was considered as the same type, a house can have a different shape in a different region across Java Island. Joglo House, for example, has some differences in shape between the southern part and the northern part of Java Island[2][3]. Considering the many types of Javanese traditional houses, this paper will limit its research in 
the structure and the use of space of Joglo House since it was more commonly found in Java Island in general.

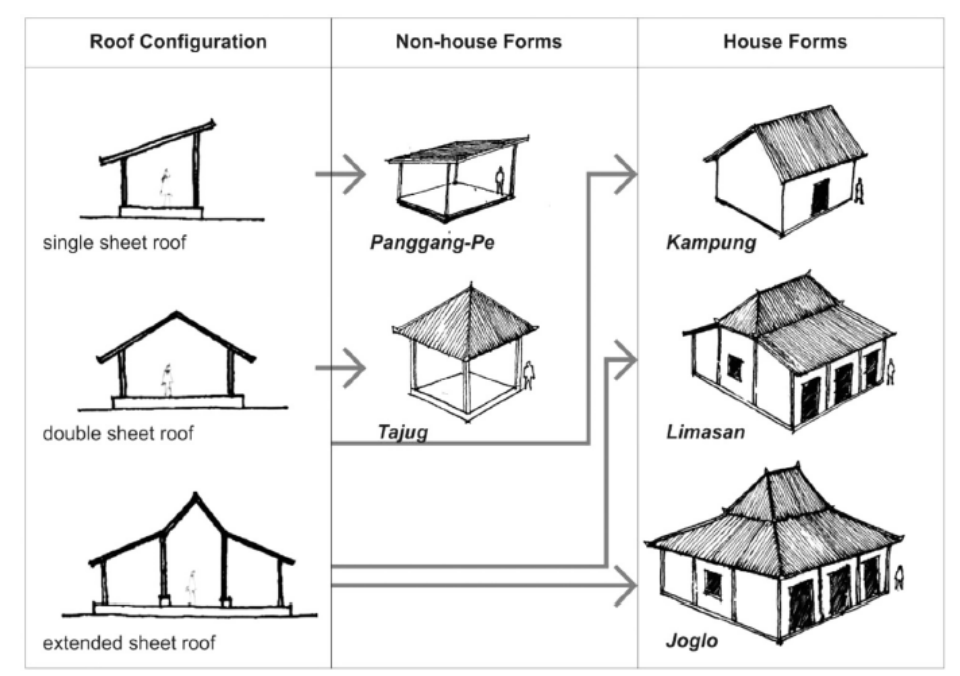

Figure 1.The many shapes of Javanese Traditional Houses [2]

The history of Joglo House began in around the 9th century which can be seen in the Javanese temple reliefs [2]. Javanese architecture has also been described in an ancient Javanese script called Kawruh Griya which was written at the end of the 19th century [4]. The existence of traditional house architecture nowadays is in accordance with social and natural conditions, it was solidified after a long trial process where homes should be resistant to environmental problems that often occur. Because of this aspect, the development of Joglo Houses was influenced by natural and social aspects, where it slowly changed the structure of Joglo House from an architectural perspective [2]. The layout in the Joglo house adapts the philosophy of Javanese culture, where each room is placed in a separate building according to its function. For example, the service area which includes kitchens, bathrooms, and wells, are located in separate buildings placed behind the main house called dalem [5][6][7]. This is different from the modern house layout where the service area is integrated into the main house. Thus, the layout of Joglo House, especially the placement of service areas in separate buildings from the main house, is interesting to be explored and examined to understand whether or not there exist any meaning or benefit behind the separation of these buildings and the architectural structure of Joglo House in general that can inspire the design of modern housing, especially to the Indonesian urban society.

\section{Methods}

This paper used a qualitative research method with exploration design to explore the architectural structure of Joglo House. The focus on examining the placement of service area in the architectural structure of Joglo House was chosen based on the results of the literature study, where the service area placement has not been much discussed in the research related to the Joglo House. The research was conducted by exploring literature and articles discussing 
Joglo Houses and comparing the data gained from the design and architectural perspective to understand the relationship between the structure of Joglo House and the Javanese culture, especially related to the unique placement of the service area in Joglo House.

\section{Results and discussion}

Joglo is a traditional Javanese house with a roof resembling a mountain with a very short mala term for ridgepole located in the top of the roof, accompanied by a symbolic structure of Tumpang Sari [5]. Tumpang Sari is an arrangement of beams in a pyramid-like structure with five, seven, or nine levels[8]. The roof of the Joglo House has a unique design that looks like it was broken into three parts, namely brunjung, penanggap and panitih, so that it is also called rumah tikelan or broken house [5]. The structure of this roof can be seen in figure 2 .

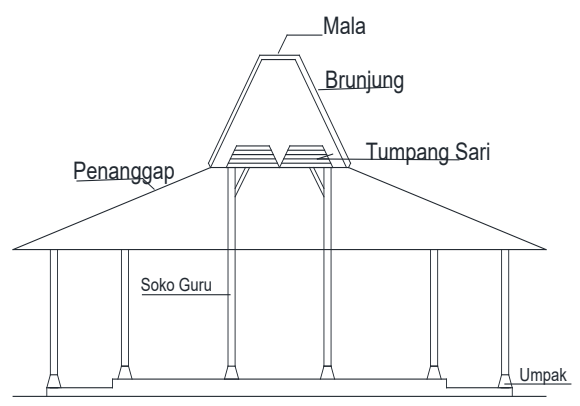

Figure 2. Sketch of Joglo House[6]

Joglo House is a Javanese traditional house that bears a distinct philosophy. The structure of Joglo House reflects the relationship influenced by Javanese mythology and cosmology that shows that home for Javanese people does not only serve as a place to live but also as a symbol of their ideology and views[9]. Javanese people also view the home as a reflection of attitude, insight, and the economic-socio-cultural status of the Javanese people[5]. In his article published in 2011,Subiyantoro stated that Javanese houses generally are built to face south which, when viewed from the Javanese mythological aspect, is a way of respecting Nyi Roro Kidul, a mythical ruler of the southern sea which represents water as a symbol of prosperity, or to face north which is a way of respecting forest as a symbol of the source of life [5]. However, the structure of Javanese house can also be attributed to the economic aspect where the Javanese community is dominantly working as a farmer. Thus, they need to take advantage of sunlight that moves from east to west to dry the paddy rice and wood all day long.

The structure of Joglo House can be examined from the horizontal and vertical perspectives. In the horizontal perspective, Joglo House consists of rooms and their division, while the vertical perspective divides the building starting from the floor up to the roof. The vertical perspective divides Joglo house into three groups which consist of the ground floor or the foot called umpak or bebatur, the body which consists of the pole and the wall, and the top consisting of the head or the roof [9]. These divisions resemble the structure found in the ancient Javanese temple which represent the upper world (gods), middle world (life), and the underworld (death)[5]. In a horizontal perspective, the room was divided into pendopo, pringitan, dalem, kitchen or pawon, gandhok, and gandri [5][6]. Sardjono stated that the 
complete layout of Javanese traditional houses consists of several buildings, namely the front house which consists of pendopo and pringgitan, the side house which consists of gandhok, the back house which consists of gadri, pawon, pekiwan, and gedogan, and the main house which consists of dalem, housing the bedrooms (senthong)[7]. The layout of a traditional Javanese house can be seen in figure 3 .

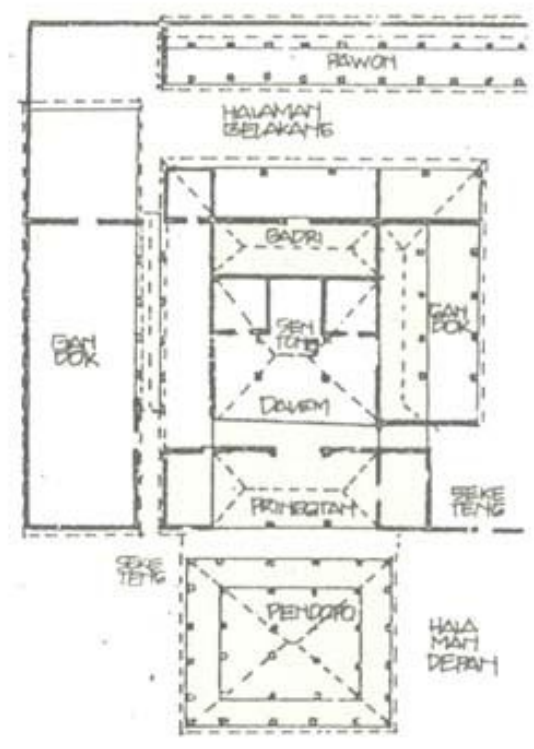

Figure 3.The layout of Joglo House[7]

Javanese people believed that every room in a Joglo House has a distinct philosophy. The pendopo functions as a guest room or a meeting room which also reflects the wisdom and the power of unity, bearing the philosophy of guyub which has the meaning of the center of harmony and the gathering place for residents from surrounding communities. The nobility sees pendopo as a symbol of protection, where the pepunden (lord) mingle with their loyal subordinates and servants of the court. The pendopo is deemed public and masculine. The building behind the pendopo is a pringgitan which is a foyer and functions as a boundary between the pendopo and the dalem. Pringgitan is a semi-open building used for puppet shows or welcoming official guests. This room also functions as an introduction before entering the main house (dalem ageng) and is semi-private. The next building is Dalem Ageng or Dalem or Omah Buri which is the main building which houses the senthong (bedroom) inside. The ground floors for Dalem are placed higher than pringgitan and pendopo. However, the floors for senthong are even higher, especially the middle senthong. The size of the door connecting the senthong and Dalem was made lower with an uneven bottom. Dalem is deemed as private, personal, and bears feminine aspect. It was meant to only accept close relatives and as a space for women's activities. The structure and the layout of pendopo and dalem reflects harmony and balance. The most private and considered as sacred space is senthong or the bedroom which stretches from east to west facing south. There are three senthong: the right senthong which was meant for the father of the family, the left senthong for the mother or the 
children when they were still little, and the middle senthong which was used for meditation so that it was made sacred and dim-lit [5]. The layout of the main building can be seen in figure 4 .

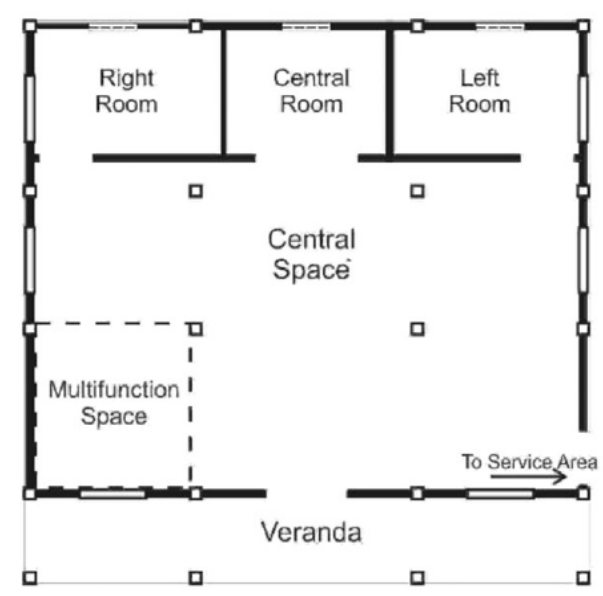

Figure 4. The floor plan of the main building for Joglo House [2]

In a complete Javanese house, there is always a gandhok consisting of two parts, which is the left and the right gandhok. The gandhok was positioned on the left and right side of the pendopo. Gandhok is used as a room for children who are already growing up and separated according to their sex. The daughter is placed on the left gandhok, while the son is on the right ones. In addition, gandhok is also used as a room for guests or for the relatives who stay overnight[5]. Behind the left gandhok and on the eastern side of the dalem, the pawon or kitchen was located. Pawonwas used to cook and as a place for leftover food and vegetables. Pawon is also used as a place to welcome female neighbors or relatives so that the pawon was meant to be a place for women. It was deemed as feminine and has a domestic function. The dining room orgadri was located behind the senthong. In Javanese houses, there exists a door on the back side of the house which represents the mean of communication, social relation, and respect. If there were a party or social event, the guests will be made oblivious of the bustling activities happening behind because the guest's needs will be delivered through this back door. This door was also used to maintain communication with the neighbor's house located behind [5].

Javanese house in general placed the service area such as kitchen, bathroom, and toilet in a separate building, detached from the main house. Pawonor the kitchen is located at the back which may or may not be connected to gadrior the dining room. Sometimes, the pawon is not only used for cooking but also functions as a storehouse. Pekiwanwhich consists of the well and the bathroom is located beside the pawon[7]. Service area service which includes pawon (kitchen) and pekiwan (well and bathroom) in Joglo House are separately located from the main house which is dalem. This is different from what commonly found in a modern house where the service area is in the house and included within the main house.

The reason behind such placements in Joglo House where pawonand pekiwan are detached from the main house is because they are considered as unsanitary and deemed as a place of privacy. In the criteria for a healthy house, the bathroom and washing room must be water proofed and easy to clean [10]. The kitchen is one of the main sources of domestic pollutant 
because of the cooking activities, resulted in a high number of ultrafine particles (UFP), PM2.5, nitrogen dioxide (NO2), dan NO gases [11]. So, the detachment made in the structure of Joglo House creates a more sanitary and cleaner environment for the main house. Aside of that, there is other advantage in detaching the kitchen from the main house. If there were any fire going on in the kitchen, then the area around the pawon or the corridor that connects the pawon with the dalem area can be demolished or destroyed so that the fire will not spread and caused further damage.

Meanwhile, the pekiwan holds another problem in the form of wastewater. Generally, the wastewater can be divided into three categories: yellow water, brown water, and greywater. The categories of yellow water and brown water includes urine dan fecal sewage. Meanwhile, greywater is the wastewater coming from bathing water, laundries, dishwashing, and the water from kitchen sinks. The yellow and brown water categories are indeed bear many harmful elements. However, the greywater coming from bathroom and toilets also contains harmful microbes such as E. Coli [12]. Water coming from the well or the wastewater of bathing and dishwashing can also cause the surrounding area to be damp, increasing the chance of moss and fungal growth that can result in a health risk [13].

Thus, the structure of JogloHouse retains the condition of the private parts of the house where residents spend more time in the family room, bedroom and living room, to be always clean, not damp, free from the kitchen fumes and the microbes that interfere with health the health of the house residents. This structure ensures the health of the house residents and maintains their comfort which will ultimately improve the quality of life of the house residents. In terms of culture and philosophy contained in the JogloHouse, unlike the pavilion which is masculine because it is more widely used for men's activities and associations with the general public, the service area located behind is a private and feminine area where this place is used for the activities of women, especially the kitchen as a place to cook.The kitchen is also used as a place to receive female guests, neighbors, and relatives.

The spirituality in the Javanese culture was manifested in the Joglo House architectural structure where there is a room specially built for meditation and prayers. The Javanese courtesy which was famous for its politeness and courteousness can be seen in the structure of the door in Joglo House, especially the door which connects to the dalem that was made lower with higher floor than the one in pringgitan (the room/building before dalem)so that the person coming will have to lower their head. This act of lowering the head is akin to bowing, showing respect for the homeowner. The placement of each of these buildings and rooms in such a way is the manifestation of the Javanese local wisdom where the people are always open, both between residents of the house and with the surrounding community and the environment without sacrificing the privacy and comfort of the house residents.

\section{Conclusion}

Discussions about Joglo House are quite numerous, ranging from the philosophy of the house, architecture, and the roof of Joglo houses. However, there were not many who discusses the placement of service areas in Joglo House which was located outside the main house. The service area in the Joglo House, consisting of pawon (kitchen) and pekiwan (wells and bathrooms) are generally separated from the main house. This separation is a reflection of the local wisdom of the Javanese people in preserving the values of Javanese culture. The separation of the location of the service area far from the main house also considered beneficial in terms of the healthy house conducts because these rooms is considered as unsanitary and deemed as a place of privacy. 
As with the case of every cultural artifact, Joglo House cannot be separated from the beliefs and culture of the local community, as well as the community interaction with their surrounding environment. The local wisdom of the Javanese people which was manifested in their traditional houses has ensured and accommodated not only the comfort of the residents and the adherence to local customs but also the harmony interaction with the surrounding environment both in relation to nature and between neighbors in the community. Thus, the study of the service area of the Joglo House reflect the importance of acknowledging traditional values and local wisdom in designing the architectural structure and constructions of the house, not only as a mean of preservation for the cultural values and local wisdom, but also to build a more effective structure that can accommodate the comfort and community interactions within society.

\section{References}

[1] S. Slamet, "The Interpretation of Joglo Building House Art in The Javanese Cultural Tradition," Mudra J. Seni Budaya, vol. 26, no. 3, 2011.

[2] N. C. Idham, "Javanese vernacular architecture and environmental synchronization based on the regional diversity of Joglo and Limasan," Front. Archit. Res., vol. 7, no. 3, pp. 317-333, 2018.

[3] M. A. Wahyudi, "Karakteristik Rumah Tradisional di Pesisir Kilen Jawa Tengah Studi Kasus Rumah Tradisional di Desa Krajan Kulon, Kaliwungu, Kendal," Teknis, vol. 10, no. 3, pp. 145-152, 2015.

[4] J. Prijotomo, "Griya dan Omah: Penelusuran Makna dan Signifikasi di Arsitektur Jawa," Dimens. Tek. Sipil, vol. 27, no. 1, pp. 30-36, 1999.

[5] S. Subiyantoro, "Rumah Tradisional Joglo dalam Estetika Tradisi Jawa," Bhs. dan Seni, vol. 39, no. 1, pp. 68-78, 2011.

[6] F. M. Sari and D. Mutiari, "Perbandingan Rumah Tinggal Tradisional Jawa dan Rumah Tinggal Modern di Surakarta," Sinektika, vol. 14, no. 2, pp. 217-224, 2014.

[7] I. Nazarudin, "Rumah Pencu Di Kudus: Kajian Berdasarkan Tipologi Dan Pola Sebaran,” Berk. Arkeol., vol. 32, no. 1, p. 51, May 2012.

[8] B. Fauzy, P. Salura, Q. A. Nasution, and C. Stephanie, Sintesis Akulturasi Arsitektur pada Masjid Al-Muttaqun di Klaten. Bandung: Universitas Parahyangan, 2016.

[9] Djono, T. P. Utomo, and S. Subiyantoro, "Nilai Kearifan Lokal Rumah Tradisional Jawa," Humaniora, vol. 24, no. 3, pp. 269-278, 2012.

[10] "Keputusan Menteri Republik Indonesia nomor 829/MENKES/SK/VII/1999 Tanggal 20 Juli 1999.” Departemen Kesehatan RI, 1999.

[11] N. A. Dobbin et al., "The bene fi t of kitchen exhaust fan use after cooking - An experimental assessment," Build. Environ., vol. 135, no. February, pp. 286-296, 2018.

[12] K. Shi, C. Wang, and S. C. Jiang, "Quantitative microbial risk assessment of Greywater on-site reuse,” Sci. Total Environ., vol. 635, pp. 1507-1519, Sep. 2018.

[13] C. Boomsma, S. Pahl, R. V Jones, and A. Fuertes, “'Damp in bathroom. Damp in back room. It's very depressing!' exploring the relationship between perceived housing problems, energy affordability concerns, and health and well-being in UK social housing," Energy Policy, vol. 106, no. February, pp. 382-393, Jul. 2017. 